\title{
A questão social: da invenção à contemporaneidade
}

\section{Inaiá Maria Moreira de Carvalho}

Universidade Federal da Bahia (UFBA)

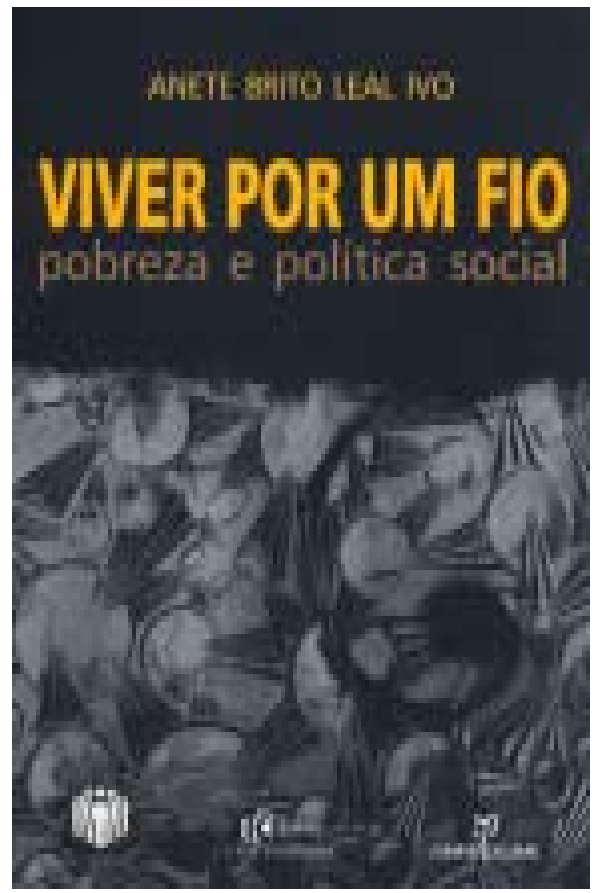

RESENHA: A questão social: da invenção à contemporaneidade

IVO, Anete B. L. Viver por um fio: pobreza e política social. São Paulo: Anablume; Salvador: CRH-UFBA, 2008. 258 p.

BOOK REVIEW: Living by a Thread: Poverty and Social Policy

IVO, Anete B. L. Living by a Thread: Poverty and Social Policy. São Paulo: Anablume; Salvador: CRH-UFBA, 2008. 258 p. 
Em uma época de tantas mudanças e incertezas, onde a globalização do capitalismo, a crise da sociedade salarial, a financeirização da riqueza e a redução das responsabilidades sociais do Estado vêm agravando as desigualdades e a pobreza, o livro $\mathrm{Vi}$ ver por um fio: pobreza e políticas sociais, de autoria da professora Anete Brito Leal Ivo constitui uma contribuição da maior relevância para o entendimento dessas questões.

Lançado no final de 2008, o livro está estruturado em duas grandes partes. Na primeira delas, a autora discute o significado da questão social, entendendo-a como uma grande invenção da modernidade, concebida nas sociedades europeias, nos séculos 18 e 19, através de um conjunto de mediações políticas e econômicas que viabilizou um novo padrão de solidariedade e um sistema de proteção social, instituídos a partir do Estado nacional. Impondo-se sobre as formas de solidariedade anteriores, atreladas à sociabilidade tradicional, essas mediações procuraram viabilizar certa coesão social diante das novas condições de desigualdade, vulnerabilidade e pobreza, associadas à expansão do capitalismo industrial, apesar de todo o crescimento da riqueza.

Nesta discussão, de uma forma inovadora e criativa, o livro recupera, desdobra e sintetiza teorizações e controvérsias de autores clássicos como Marx, Engels, Tocqueville, Durkeim e Simmel sobre o pauperismo, ao lado da contribuição da literatura nacional e internacional contemporâneas. Aborda a dimensão prática do projeto sociológico, expresso nos princípios da objetivação e intervenção nacional sobre a vida social. Analisa o enigma brasileiro da questão social, mostrando como ela se expressa na persistência de uma massa de pessoas que se reproduz nos limites mínimos da subsistência e fora das atividades econômicas dominantes. Apresenta a trajetória dessa questão, os debates que se deram sobre a mesma no processo de modernização do país e as novas tendências das décadas de 1980 e 1990.

A segunda parte do livro aborda o que a autora denomina de "reconversão do social", ocorrida a partir dos anos 1990, quando a reestruturação produtiva e a integração periférica do Brasil à economia globalizada comprometeram as conquistas obtidas até a Constituição de 1988. Essa conjuntura promoveu o encaminhamento da questão social de um paradigma universalista para ações focalizadas da política social, com a desconstrução de um Estado de Bem-Estar que não chegara a se conformar plenamente. Essa abordagem identifica os dilemas do capitalismo periférico nessa nova etapa da acumulação, marcada por um crescimento débil, instável e altamente dependente dos fluxos internacionais, assim como pela dissocialização do trabalho. Aponta os efeitos dessas mudanças sobre as condições de cidadania, sobre a estratificação e a segmentação entre cidadãos pro- tegidos e a população de assistência, classificada como "coletivos de destino". Estima a dimensão dessa população e, com dados novos e pertinentes, avalia as políticas focalizadas e os programas de transferência de renda, com ênfase no Benefício da Prestação Continuada e no Bolsa Família, apontando seus resultados e limitações.

Ao longo dessas análises são discutidas e esclarecidas noções básicas para o debate contemporâneo, como as de vulnerabilidade, desfiliação e exclusão; enfrentadas controvérsias e aprofundadas questões como a influência das agências multilaterais nas políticas de combate à pobreza, a governança democrática, a focalização das políticas sociais e a desconexão recente entre trabalho e proteção.

As conclusões do livro procuram articular os processos de reconversão da questão social com mudanças paradigmáticas da Sociologia, expressas na emergência de novas categorias da prática e de atores sociais estratégicos na reconfiguração da ordem social.

Sem que isto prejudique a sua compreensão, trata-se de um trabalho bastante denso, profundo e informativo, que recupera o debate histórico, avança e inova na compreensão dos processos contemporâneos. Coloca em um novo patamar o entendimento da questão social, das desigualdades, da pobreza e das políticas sociais no Brasil, o que torna sua leitura indispensável para professores, profissionais, estudantes e todos aqueles que estão preocupados com uma compreensão crítica e com o enfrentamento do enigma social brasileiro.

\section{Inaiá Maria Moreira de Carvalho \\ inaiammc@ufba.br}

Doutorado em Sociologia pela Universidade de São Paulo (USP)

Professora do Mestrado em Políticas Sociais e Cidadania da Universidade Católica do Salvador e do Programa de Pós-Graduação em Ciências Sociais da Universidade Federal da Bahia (UFBA)

\section{UFBA - Programa de Pós-Graduação em Ciên- cias Sociais}

Estrada de São Lázaro, 197

Federação

Salvador - Bahia - Brasil

CEP: 40210-730 